\title{
Agenda setting: Policy change and policy dynamics A brief introduction
}

\section{Felipe Gonçalves Brasil 1}

Bryan D. Jones ${ }^{2}$

1 Universidade Estadual Paulista "Júlio de Mesquita Filho", Araraquara / SP - Brazil

2 University of Texas at Austin, Texas - United States of America

This Thematic Special Issue on Policy Change and Policy Dynamics has as its main objective to present and discuss agenda setting, one of the most important issues for the study of public policies and the policy process. The agenda setting approach proposes an analytical approach on pre-decision processes to understand broader developments in public policy. To achieve that, it places the attention at the center of political action and relies on the fact that it is the change in attention that would cause, consequently, change in public policy. One of the most relevant aspects on the studies of policy agendas and policy change considers the diffusion occurred in the years 2000 with the application of its theoretical and methodological approaches to different societies and political systems beyond the United States. Consequently, another important achievement in the studies of agenda setting and policy change must be highlighted: studies of public policies in comparative perspective. Although agenda-setting studies have grown significantly in the international academic community, there are still some important points to be better explored. The intent of this Themed Special Issue of RAP is to contribute with the growing agenda-setting studies by highlighting the processes of policy changes and policy dynamics.

Keywords: agenda-setting; policy change; policy dynamic; policy attention.

\section{Agenda Setting: mudanças e a dinâmica das políticas públicas Uma breve introdução}

Esse artigo é uma breve apresentação do número Especial Temático sobre Mudança e Dinâmicas de Políticas Públicas, que tem como objetivo principal apresentar e discutir os conceitos envolvidos no processo de agenda-setting, um dos temas mais importantes para o estudo das políticas públicas e do processo de políticas públicas (policy process). Os modelos de definição de agenda (agenda-setting) propõem abordagens analíticas sobre os processos pré-decisórios para a análise e compreensão de aspectos mais amplos na construção de problemas e soluções em políticas públicas. Para tanto, coloca a atenção, um recurso escasso, no centro da ação política, indicando que é a mudança de atenção que ocasionaria, consequentemente, mudanças em políticas públicas. Um dos aspectos mais relevantes nos estudos de agenda-setting e mudanças em políticas públicas considera a difusão global de seus estudos ocorrida nos anos 2000 com a aplicação de abordagens teóricas e metodológicas a diferentes países e sistemas políticos, para além Estados Unidos, de onde tais modelos e teorias surgiram nos anos 1980 e 1990. Consequentemente, outra conquista importante nos estudos de definição de agenda e mudança de políticas deve ser destacada: os estudos de políticas públicas em perspectiva comparada. Embora os estudos de definição de agendas tenham crescido significativamente na comunidade acadêmica internacional, ainda existem alguns pontos importantes a serem mais bem explorados. A intenção deste Número Especial, é o de contribuir com os crescentes estudos sobre agenda-setting, destacando os processos de mudanças e as dinâmicas das políticas públicas.

Palavras-chave: agenda-setting; formação da agenda; mudança em políticas públicas; dinâmica de políticas públicas e atenção em políticas públicas. 


\section{Agenda Setting: cambios y dinámica de las políticas públicas Una breve introducción}

Este artículo es una breve presentación del número Temático Especial sobre Cambio y Dinámica de las
Políticas Públicas, cuyo principal objetivo es plantear y discutir los conceptos involucrados en el proceso de
establecimiento de la agenda (agenda-setting), uno de los temas más importantes para el estudio de las políticas
públicas y de su proceso (policy process). Los modelos de agenda-setting proponen enfoques analíticos de los
procesos predecisorios para el análisis y comprensión de aspectos más amplios en la construcción de problemas
y soluciones en las políticas públicas. Para ello, pone la atención -un recurso escaso- en el centro de la acción
política, indicando que es el cambio de atención lo que, en consecuencia, provocaría cambios en las políticas
públicas. Uno de los aspectos más relevantes en los estudios de agenda-setting y cambios en las políticas públicas
considera la difusión global de sus estudios que se dio en la década del 2000 con la aplicación de enfoques teóricos
y metodológicos a diferentes países y sistemas políticos, más allá de Estados Unidos, donde dichos modelos y
teorías surgieron en las décadas de 1980 y 1990 . Consecuentemente, cabe destacar otro logro importante en los
estudios de establecimiento de agenda y cambio de políticas: los estudios de políticas públicas en perspectiva
comparada. Aunque los estudios de establecimiento de agendas han crecido significativamente en la comunidad
académica internacional, todavía quedan algunos puntos importantes por explorar más a fondo. La intención
de este Número Especial es contribuir a los crecientes estudios sobre agenda-setting, destacando los procesos
de cambio y la dinámica de las políticas públicas. Palabras clave: agenda-setting; formación de agenda; cambio en políticas públicas; dinámica de las políticas públicas y atención en políticas públicas.

\section{INTRODUCTION}

Finding a starting point to discuss the formation and development of a field of knowledge is a major challenge for any researcher, especially in the humanities and social sciences. This happens because ideas change over time. Concepts, terms and definitions are constantly recovered, reframed and reused to explain new political and social phenomena and for the construction of new definitions and theories. In studies of the formation of the governmental agenda, the challenge is no less. The starting point here, could be defined in the relationship between the governmental agenda, public opinion agenda and media agenda, rescuing main authors such as Lippmann (1922), Lazarfeld (1944), highlighting the works of Cohen (1963) and research empirical statements by McComb and Shaw (1972). Another possible way for us to start the debate on the agenda-setting process, would take in account the original contribution of Lasswell (1951) that relates policy sciences to the strengthening of democracy. The study of how problems are constructed and understood in political communities points to an important relationship between problem definition and democratic theory. Along these lines, authors such as Schattschneider (1960), Bachrach and Baratz (1962) are essential to the debate that puts the role of conflict mobilization and expansion at the forefront, and non-decision, as forms of government action.

\section{GOVERNMENTAL AGENDA-SETTING AS A FIELD OF STUDY}

As the objective of this special issue is to prioritize the most recent studies and models of the process of forming and changing the governmental agenda, we chose to start this introduction with the appearance of the term "agenda". Initially formulated under the term "agenda-building", 
this field of study has its origin in the United States, in the early 1970s, with the pioneering works of Cobb and Elder $(1971,1972)$. Agenda-setting is defined, therefore, as a process of transforming private issues into public ones, and these into government priorities. The authors defined the term agenda as "a general set of political controversies that will be viewed as falling within the range of legitimate concerns meriting the attention of the polity" (Cobb \& Elder, 1971, p. 905) and further advanced to a more detailed conception of "institutional agenda" defined as "to denote a set of concrete items scheduled for active and serius consideration by a particular institutional decision-making body" (Cobb \& Elder, 1971, p. 906). Between these two concepts of agenda, the authors showed, initially, how a theme could shift, moving from a general (or systemic) agenda to an institutional agenda. An innovation brought by Kingdon (1984) - the decisional agenda shows a process in motion.

When conceptualizing the agenda-setting process, the authors identify and differentiate two stages by which issues are perceived as public problems. The first stage is defined by the systemic agenda. It contains all issues that receive the attention of society and that are perceived as problems or issues that must be addressed by the government or decision makers. The second stage is the governmental agenda, composed of the attention of decision makers and government officials on the issues and themes that they themselves consider important. The formation of the agenda still undergoes a new update with the studies of John Kingdon, in 1984, with the creation of a new dimension called the decision-making agenda. The decision-making agenda is understood as a minor part of themes present in the governmental agenda that not only draw the attention of policymakers as public problems, but are also in conditions for action by policy makers.

From these characteristics on the process of forming the governmental agenda, the role of attention on issues and understanding these as priority public problems is highlighted. Attention is a scarce and limited resource. It is not possible to pay attention to all problems at the same time. More than that, it is not even possible to recognize the existence of all the issues and problems that exist in a society. Based on these findings, it is essential for the public policy process to understand which themes gain the attention of decision makers, and how this prioritization process occurs.

John Kingdon (1984) was the one who mastered and distinguished the government agenda literature by saying that the definition of an agenda is much greater than simply a cacophony of public and private affairs. It involves more than a jumble of issues that groups and institutions see as urgent and subject to immediate publication. Scheduling is marked by a process of filtering themes and subjects that depends not only on the individual values of the actors or institutions involved, but also on the perception these actors have whether the prioritized subject has the potential to be executed. This finding does not imply that decision makers only prioritize issues that can be resolved: there are values and intentions implicit in this process. The central issue, at this point, boils down to the fact that, if the agenda-setting is defined by the formation of priorities, the capacity to act on a topic can be a relevant indicator for this process of hierarchization and filtering of subjects. Likewise, it is necessary to point out that problems (issues) are social constructions that need to be analyzed in a certain time and context. Cultural, temporal and institutional differences 
are important variables for understanding the process of priorities in a society. What is considered a priority in a given society may not, for long periods, become the object of government action in another society. Moreover, within the same society, the temporal analysis can show how issues enter and leave the government's agenda of priorities according to the decades, or even according to the political parties in the government. These are the variations that make the agenda-setting process a fluid and dynamic phenomenon, subject to moments of long periods of stability, with timid and incremental changes, but also punctuated by ruptures and strong changes, as described by Baumgartner and Jones (1993).

\section{PUNCTUATED EQUILIBRIUM}

In the 1990s, Frank Baumgartner and Bryan Jones (2009) applied the notion of punctuated equilibrium to the policy process, in which long periods of stability in policymaking are occasionally interrupted by large-scale change. Prior to that work, the policy models of the period emphasized gradual change and balance among different interests in politics. Such changes could occur through elections, but they could also occur policy-by-policy, within what public administration scholars call policy subsystems. Examples of policy subsystems include environmental regulation, defense policy, and management of the governmental financial system. They can involve few actors, as for example forest management does in normal times, or be more extensive networks, as defense procurement is (McGee \& Jones, 2019). Balance within subsystems occurred because affected interests, such as loggers, sportsmen, and environmentalists, worked out policy in conjunction with government officials, usually out of the limelight of public opinion.

The traditional view of subsystem policymaking excluded public opinion and the activities of political parties. What occurs when a larger segment of the public becomes mobilized? This could happen because of vast wildfires in the Western U.S., or the rapidly increasing exploitation of the Amazon, leading to a shift in ecology from rainforest to savannah, destroying livelihoods and native communities. During these periods of heightened public attention, political parties, elected political executives, and even broader social movements get involved in what was previously left to interested groups and bureaucrats, and policies can be altered in major ways.

Scholars of the policy process have recognized these different modes of policymaking — subsystem politics on the one hand, and what is termed macropolitics, or the politics of large scale, on the other. The major issue is how policies move from one domain to another (Redford, 1969; Schattschneider, 1960). It is this mobilization that punctuated equilibrium addressed and built into a broader model of policy change.

While one possibility is the expansion of the conflict from the subsystem to the broader political system, it is also possible that collective attention will decline, and the policy subsystem could go back to business as usual. That occurs in many, and probably most, cases of heightened public alarm (Downs, 1972). Forest management mostly will return to equilibrium in which public officials defer to whatever logging and environmental interests can work out. In some cases, however, large-scale policy changes do occur, leading to a pattern of long periods of stability punctuated by occasional large-scale changes - punctuated equilibrium. 


\section{THE GENERAL PUNCTUATION THESIS}

The dynamics of punctuated equilibria in policymaking is driven by a politics of attention. When collective attention is sparse, there is little motive to make major changes. When it is focused and sustained, major changes are possible. When do such punctuations occur?

In 2005, Jones and Baumgartner (2005) developed a more general approach to the dynamics of punctuated equilibrium. They termed this the general punctuation thesis, which conceives of government as facing a whole array of policy problems that need addressing. Policymakers must recognize the problem, gauge its severity, rank it among the competing problems, and decide what action to take. Ideally policymakers would devote enough resources to solve the problem but not so many resources that the solution would be inefficient.

Political systems are subject to multiple streams of information on these problems, yet they are also subject to a great deal of resistance to acting on those problems (Jones \& Baumgartner, 2012). The information is always uncertain and ambiguous, and hence seldom clear enough to make the appropriate action obvious. Moreover, just as people cannot pay attention to everything at once, neither can policymaking institutions. As a consequence, there is always a delay in acting, with political actors ignoring or downplaying the severity of the problem. This leads to a tendency to allow problems to fester until they cross a threshold of criticality and are so severe that they can no longer be ignored (Jones \& Baumgartner, 2005).

Limits on attention are a major impediment to responding to information in all systems, but this is intensified when information is suppressed or distorted, as it can be in political exchanges. The debate on climate change has been fraught with disinformation designed to mislead the public and deter or at least delay major action on what is a clear and increasing problem. In both the U.S. and Brazil, political leaders have mounted major disinformation campaigns to deter major action to address the coronavirus pandemic, with frightening results of heightened disease, deaths, and disabilities compared to countries that more forthrightly addressed the scientific information.

A second form of resistance exists as well. It is the set of decision rules that allow some actors with sufficient political authority - termed veto players - to stymie such action and ideological rigidities that interfere with the recognition of and response to problems (Jones, Sulkin, \& Larsen, 2003; Tsebelis, 1995). In the U.S., the federal government acted quickly to provide massive economic relief early in the pandemic after alarmed discovery of the problem motivated action, but has been unable thus far to provide further relief that most economists and political leaders think is necessary because of the system of separated powers requiring coordinated action.

While the politics of attention is primarily concerned with under-reaction to problems due to resistance to adequate action by intrenched interests, alarmed discovery can in some cases lead to overreaction and policy bubbles (Jones, Thomas, \& Wolfe, 2012; Maor, 2014). A policy bubble is similar to an economic bubble in that policymakers bid up the response to a real or perceived problem, leading to an oversupply of government resources directed at the issue. This happened in the U.S. for the increasing crime rates in the 1970s, leading to what is now termed the "prison-industrial complex" 
- basically a policy subsystem most responsive to political actors benefiting from over-incarceration. Unlike economic bubbles, policy bubbles are hard to reverse, because the policy changes have created a new policy subsystem of interested actors that try to protect the gains they have garnered via the policy bubble.

\section{STICK-SLIP DYNAMICS}

The key to policy change in the General Punctuation Thesis is the interaction between the flow of information and demands for change to address a festering problem, on the one hand, and the friction or resistance mounted by veto groups and contrary information. The tension between the demands for action generated by flows of information and the resistance to them leads to a stick-slip dynamics, the same kind of process that generates earthquakes as tectonic plates stick for long periods of time (the friction) then suddenly slide rapidly along each other as pressure from the earth's core increases tension between the plates (Jones \& Baumgartner, 2012). ${ }^{1}$ This dynamic leads to a distribution of policy changes that has mostly very small, incremental policy changes, a few really big changes, and fewer moderate changes adapting to the severity of the problem the political system faces. Policymakers either ignore the problem while it festers or overreact to it when it reaches almost unmanageable proportions.

Sometimes the failure to act because of resistance to doing so leads to a dilemma in which political authorities face only two very bad choices. For example, in the Spring of 2020, the U.S., like many other nations, instituted draconian policies to stop what had become a rapid spread of the coronavirus through the population. Policymakers shut down many businesses, put limits on the size of gatherings, and instituted stay-at-home, social distancing, and mask-wearing. In May, with the case number stabilizing, many states re-opened. But cases of the disease had not been lowered to an adequate level to staunch the spread of the virus, according to most epidemiologists. The result was a rapid resurgence of the virus. The only reliable solution was another dramatic shutdown, resulting in a major policy change on the magnitude of the first intervention. By ignoring the scientific information, the total policy intervention would have to be much bigger than if the policies instituted in the spring had remained in place a little longer. Political resistance to the proper policy intervention caused the problem to reemerge, presenting policymakers with the dilemma of either living with the dire consequences or instituting another massive and expensive intervention.

\footnotetext{
${ }^{1}$ The above discussion is drawn from Jones, Epp, and Baumgartner (2019).
} 


\section{PRESENTING THE SPECIAL NUMBER}

The editors and collaborators of the Brazilian Journal of Public Administration (RAP) prepared this special issue to connect Brazilian and Latin American researchers, students, practitioners, and other interested parties with the most recent approaches, methods, theories, and applied studies on agenda-setting and policy change. After an open call for papers and a thorough editorial process, this special issue selected 12 articles produced by 28 authors from 10 different countries (Belgium, Brazil, Colombia, Ecuador, Spain, United States, France, Guatemala, Italy, and the United Kingdom). The articles present different theoretical approaches, methods, analytical tools, and objects, reflecting the multi-disciplinary and inter-sectoral nature of this field of studies.

The articles offer theoretical reviews and studies applying different models and approaches to agenda-setting and policy change, such as multiple streams, punctuated equilibrium, defense coalitions, narrative approach, and policy learning. The authors propose methods for monitoring and analyzing policy attention, exploring its relationship with agenda-setting and changes in governmental agenda. Their work presents qualitative analyses based on interviews and process-tracing, quantitative comparative studies, as well as bibliometric studies on the recent Brazilian production and the application of synthetic models in theses and dissertations. The articles present a variety of research objects analyzed in case studies, which cover different sectoral policies such as anti-drug policies, rural water supply and sanitation policies, large-scale changes in the environment, science, technology and innovation (ST\&I) policies, affirmative action policy in higher education, and cross-sectional studies, which address the policymakers' attention to various sectoral policies over time.

The diversity of approaches, methods, and objects analyzed in this special issue reflects the growth, diffusion, importance, and plurality of the field of public policies and, more specifically, of studies on agenda-setting and policy change around the world. Bringing this debate and applications closer to the context of Brazil and Latin America, connecting researchers and studies in development, is crucial to strengthen and disseminate studies and to build a solid and structured field.

This special issue begins with two guest articles, one focusing on Brazil and the other with an international scope. In the first article, "Policy agenda-setting studies: an overview of Brazilian research", Professor Ana Cláudia Capella, leading scholar of agenda-setting studies in Brazil and one of the main interpreters of this literature in the country, presents a fundamental systematic review to chronologically understanding the evolution of the main assumptions, concepts, and analytical models on agenda-setting at the international level. Professor Capella emphasizes the contribution of Cobb and Elder in the U.S. in the 1970s, of John Kingdon (1984) and his multiple streams model, and the inputs by Baumgartner and Jones (1993) and their punctuated equilibrium theory. The article shows the scenario of the Brazilian research on the topic, exploring adaptations and uses of these theoretical models. The review demonstrates the construction of public policy studies in Brazil, analyzing doctoral dissertations and master's theses focusing on agenda-setting. Capella found 161 works produced between 2000 and 2018, with a clear growth of production from the 2010s. 
The second guest article, "Agenda dynamics in Latin America: theoretical and empirical opportunities", by Frank Baumgartner, Bryan Jones, and Laura Chaqués Bonafont, introduces the Comparative Agendas Project (CAP). The study presents CAP's history and the key concepts structuring what is nowadays one of the most important international research groups in the field of public policy. Baumgartner and Jones created the punctuated equilibrium theory and the U.S Policy Agendas Project, which originated the CAP. Laura Chaqués Bonafont is the general coordinator of the Spanish Policy Agendas and one of the most respected researchers of CAP. The authors highlight the development of CAP in the U.S. and its dissemination throughout Europe in the 2000s, showing the construction of country-level projects tackling different contexts and political systems. They highlight the debates on indicators that explain the dynamics of change in the local contexts without losing the ability to carry out international comparative analysis. Finally, the article by Baumgartner, Bryan, and Bonafont contributes to future agendas by systematizing the recent wave of dissemination of CAP in Latin America. The study points out research challenges and opportunities beyond regional limits, observing a wider analytical and geographical scope that leads to a more diverse and disseminated CAP. Shaun Bevan and Anna Palau advance the debate on constructing new CAP projects in Latin America in the third article of this special issue, "The Comparative Agendas Project in Latin America: Data and Coding". The authors focused on methodological and analytical aspects that structure the projects related to CAP, offering details on the coding system adopted, and highlighting the tools to capture political attention in a comparative manner over time. Bevan and Palau reflect on the production of recent data in Latin American countries, with examples from Brazil, Colombia, and Ecuador, discussing the types of locus and data sources researchers in Latin America have chosen to conduct their studies.

These first three articles provide a broader, theoretical, and methodological overview of agenda-setting studies and the dynamics of change in governmental agenda. They allow readers to approach or recall the main concepts used when addressing the topic, understanding CAP's history, and tapping into opportunities for future research. The fourth, fifth, and sixth articles of this issue form a second group of contributions emphasizing case studies approaching both the dynamics of policy attention in domestic and comparative perspectives. Pablo Aguirre's contribution "Case study: what did Rafael Correa say? Comparing political attention across 10 years of the Ecuadorian president's discourses", presents a systematic analysis of policy priorities based on the official speeches of Ecuador's former president, explaining the main topics addressed. The author also uses the speeches to describe and discuss the president's agenda-setting and the changes in policy attention over time.

The fifth article, "The Colombian Political Agendas Project: analysing presidential attention during the administrations of Uribe and Santos (2002-2018)", by Juan Guillermo Vieira Silva and Jeraldine Alicia del Cid Castro, presents a case study on the dynamics of presidential policy attention in Colombia from 2002 to 2018, covering the administrations of Álvaro Uribe (2002-2010) and Juan Manuel Santos (2010-2018). The authors studied the instruments used by the Colombian presidents to establish priorities and act, underlining the CONPES (national council of social and economic 
policies) and bills. The documents related to these two instruments formed a database of more than 44 thousand observations, which were analyzed in three parts. The first part presented the dynamics of prioritizing public policy issues. The second analyzed how the attention was distributed between the two selected instruments. Finally, the third part of the analysis established connections between the type of public policy and the instrument used (CONPES or bill), demonstrating and discussing the existence of a strategic dynamic to conduct political issues with specific instruments. The sixth article, "Parliament's (lack of) agenda-setting power over the executive decision agenda: evidence from Belgium, France and Portugal", adopts an agenda-setting perspective to offer a comparative analysis of the relationship between the legislative and executive branches in the three countries. The authors Enrico Borghetto, Julie Sevenans, and Emiliano Grossman examine the relationship between the attention the legislatures put on specific public issues, observed through parliamentary questions, and the executives' decision agenda, identified in the topics addressed in the weekly meetings of the Council of Ministers in the three countries. The authors used a common methodological structure to collect data and organized the information from the countries into three different data sets, obtaining more than 90 thousand observations. The result of multivariate analyzes showed the executive's agenda-setting dominance and the little influence of legislatures in executive decisions.

The third group of articles in this special issue presents national and international case studies demonstrating the construction and application of different analytical models, methods, and tools, as well as the elaboration and implementation of sectoral policies. The seventh article, "Narrative reinventions as cognitive mechanisms for public policy stability: the case of anti-drug policy in Colombia", adopts the narrative policy framework as the main theoretical framework to study stability and policy changes to combat illegal drugs in Colombia. The author, Jairo Santander, uses discourse analysis and relies on cognitive and interpretive perspectives to discuss the social constriction of the problem, its solutions, and the paths adopted within the Colombian anti-drug policy. Damasio Duval Rodrigues Neto and Márcio Barcelos also adopt the narrative approach in the eighth article, "Stories in the agenda: a Narrative Policy Framework study" The authors analyze the creation and agenda-setting of affirmative action policies at the Federal University of Pelotas, in Rio Grande do Sul, Brazil, highlighting the centrality of ideas, values, and interests in the policymakers' agenda. These elements were considered the main sources to analyze the social construction of reality and understand narratives strategically built during the elaboration of public policies. For the authors, "ideas matter," especially when symbolic disputes are at the core of the policymaking process.

The ninth article, "Access to the Brazilian agenda of the national rural water supply and sanitation project (1985)", by Roland, Heller, and Rezende, adopts John Kingdon's multiple streams model as the main theoretical framework. The study takes the reader back to the mid-1980s, in a detailed analysis of the agenda-setting process of the Brazilian National Rural Water Supply and Sanitation Project. John Kingdon is the pioneer of a new generation of studies on policymaking 
and policy change, and his concepts and ideas are directly or indirectly present in all studies published in this special issue. Roland, Heller, and Rezende thoroughly recreate Kingdon's metaphor of the three streams to explain the complex agenda-setting and formulation process of the project in the 1980s, showing that the country had, at that time, the appropriate conditions to include the initiative in its agenda.

The last three articles of this special issue of the Brazilian Journal of Public Administration (RAP) offer analyses on different sectoral policies, using the advocacy coalition framework (ACF). Sabatier and Jenkins-Smith's ACF, John Kingdon's multiple streams model, and Baumgartner and Jones' punctuated equilibrium theory, are the most well-known and relevant basis for studies on government agenda-setting and policy change. Understood as synthetic models to analyze policymaking processes, they may apply to different types of sectoral policies, as the following articles demonstrate. The tenth study, "Policy learning and policy change: exploring possibilities on the Advocacy Coalition Framework", by Janaina Ma and Diego Mota Vieira, offers a theoretical analysis that connects and relates the main concepts of the ACF and policy learning. Despite skepticism - not to say pessimism - regarding the processes of learning and building knowledge for policymaking, the authors develop a reasoning that not only presents a broader concept of what is learning and its relationship with knowledge; but also introduces a conceptual model, built from the dialogue between ACF and policy learning, for future applications in empirical analysis.

The article, "Large-scale environmental policy change: analysis of the Brazilian reality" is a masterpiece written by four renowned researchers, experts in the application of the ACF in Brazil: Mauro Capelari, Suely Araújo, Paulo Calmon, and Benilson Borinelli. In addition to presenting a brilliant theoretical review on Sabatier and Jenkins-Smith's model, the authors highlight international and Brazilian studies, analyzing the complex process of change in Brazilian environmental policy. Their research encompasses several actors and institutions organized around values, ideas, and interests, and focuses on the confluence of external and internal shocks to the subsystem of environmental policy currently occurring in the country.

The last work published in this issue shows the study by Diana Rodrigues, Mário Vasconcellos Sobrinho, and Ana Maria de Albuquerque Vasconcellos, "Advocacy coalition formation and key actors within the policy". The article presents a case study on policymaking in subsystems of science, technology, and innovation in the state of Pará, Brazil, and focuses on the process of agenda-setting and policy change, highlighting the role of actors - identified based on the concepts of policy broker and policy entrepreneur - in social inclusion. The case addresses an interesting topic of public policy studies worth being included in this special issue: the analysis of subnational policies considering their relationship with national guidelines.

This special issue seeks to deepen and disseminate studies on agenda-setting and policy change, bringing together researchers, students, practitioners, and other interested parties in an important and decisive, but often overlooked, moment of the public policy process. Revisiting 
RAP | Agenda setting: Policy change and policy dynamics

the main authors, theories, analytical models and, above all, dialoguing with different authors working with different policies and approaches, coming from the most diverse countries, is indeed an opportunity for learning and development of the field. For this reason, we, Felipe Brasil and Bryan Jones, thank all the authors who submitted their work, reviewers, members of RAP's staff, and editors who collaborated with this special issue, honoring and encouraging the production of knowledge in this field that is still little explored.

To each one of you, our thanks!

We wish you all a pleasant read. 


\section{REFERENCES}

Bachrach, P., \& Baratz, M. S. (1962, December). Two Faces of Power. American Political Science Review, 56(4), 947-952.

Baumgartner, F. R., \& Jones, B. D. (2009). Agendas and Instability in American Politics (2nd ed.). Chicago, IL: University of Chicago Press.

Cobb, R. W., \& Elder, C. D. (1971, November). The Politics of Agenda-Building: An Alternative Perspective for Modern Democratic Theory. Journal of Politics, 33(4), 892-915.

Cobb, R. W., \& Elder, C. D. (1972). Participation in American Politics: The dynamics of agenda building. Boston, MA: Allyn \& Bancon.

Cohen, B. C. (1963). The press and foreign policy. Princeton, NJ: Princeton University Press.

Jones, B. D., \& Baumgartner F. R. (2005). The Politics of Attention. Chicago, IL: University of Chicago Press.

Jones, B. D., Epp, D., \& Baumgartner, F. R. (2019). Democracy, Authoritarianism, and Policy Punctuations. International Review of Public Policy, 1(1), 7-26.

Kingdon, J. (2003). Agendas, Alternatives, and Public Policies (3rd. ed.). New York, NY: Harper Collins.

Lasswell, H. D. (1951). The policy orientation. In: H. D. Lasswell (Ed.), The Policysciences: Recent developments in scope and method. Palo Alto, CA: Standford University Press.
Lazarsfeld, P. F., Berelson, B., \& Gaudet, H. (1944). The People's Choice: How the Voter Makes Up His Mind in a Presidential Campaign (2nd. ed.). New York, NY: Columbia University.

Lippmann, W. (1922). Public opinion. New York, NY: Harcourt Brace.

Mccombs, M., \& Shaw, D. (1972). The agenda-setting function of mass media. Public Opinion Quarterly, 36(2):176-187.

Jones, B. D., Sulkin, T., \& Larsen, H. (2003). Policy Punctuations in American Political Institutions. American Political Science Review, 97(1) 151-169.

Jones, B. D., Thomas, H., III, \& Wolfe, M. (2014). Policy Bubbles. Policy Studies Journal, 42(1), 146-171

Maor, M. (2014). Policy Bubbles: Policy Overraction and Policy Feedback. Governance, 27(3), 469-87.

Mcgee, Z. A., \& Jones, B. D. (2019). Reconceptualizing the Policy Subsystem: Integration with Complexity Theory and Social Network Analysis. Policy Studies Journal, 47(S1), S138-S158.

Redford, E. (1969). Democracy in the Administrative State. Oxford, UK: Oxford University Press.

Schattschneider, E. E. (1960). The Semisovereign People. New York, NY: Holt, Reinhart \& Winston.

Tsebelis, G. (1995). Decision Making in Political Institutions. British Journal of Political Science, 25, 289-325.

\section{Felipe Gonçalves Brasil}

https://orcid.org/0000-0001-7282-0110

Is Postdoc Researcher at UNESP Araraquara - FAPESP Scholarship - and co-leader of the Brazilian Policy Agendas Project; Was an Intern researcher at The University of Texas at Austin - USA; He holds a Ph.D. in Political Science (Federal University of Sao Carlos); He has already received his M.A in Political Science (Federal University of Sao Carlos) and his B.A in Public Policy (University of São Paulo). E-mail: fbrasil.pp@gmail.com

\section{Bryan D. Jones}

Is the J. J. "Jake" Pickle Regent's Chair in Congressional Studies in the Department of Government at the University of Texas at Austin.E-mail: bdjones@austin.utexas.edu 